Интернет-журнал «Науковедение» ISSN 2223-5167 http://naukovedenie.ru/

Том 7, №1 (2015) http://naukovedenie.ru/index.php?p=vol7-1

URL статьи: http://naukovedenie.ru/PDF/66EangVN115.pdf

DOI: 10.15862/66EangVN115 (http://dx.doi.org/10.15862/66EangVN115)

Ntukidiem Inimfon Imaenyin ${ }^{1}$

Peoples' Friendship University of Russia

Russia, Moscow

E-mail: inimfonimaenyin@yahoo.com

\title{
Agriculture in Nigeria: identifying opportunities for increased commencialization and investment
}

${ }^{1}$ Nigeria 


\begin{abstract}
The article is dedicated to the development of Nigerian agriculture. The country is now the largest producer of cassava roots and yam tubers. Agriculture in Nigeria is a major branch of the economy in Nigeria, providing employment for $70 \%$ of the population. However farming in Nigeria is highly risky. Droughts and epizooty can cause essential damage to a rural producer. In order to reduce risks of agrobusiness in Nigeria , the state took measures for adoption of the laws promoting development of low-risk agrarian production.The Nigeria Incentive-Based Risk-Sharing System for Agricultural Lending (NIRSAL) is a new innovative mechanism targeted at de-risking lending to the agricultural sector. The Federal Government will support the development of private sector driven-marketing organizations to grow the agricultural sector. Growth Enhancement Support Scheme (GESS) represents a policy and pragmatic shift within the existing Fertilizer Market Stabilization Program. Thus today the programs directed on infrastructure improvement, creation of jobs and shared wealth in rural areas develop in agrarian and industrial complex of Nigeria. There's an Agricultural Transformation Agenda Support Program Phase 1 (ATASP-1) among them. There are factors constraining agricultural performance(resource constraints; socioeconomic constraints, organizational constraints). The author suggests ways to overcome these limitations.
\end{abstract}

Keywords: nigerian agriculture; farming in Nigeria; rural producer; Nigeria Incentive-Based Risk-Sharing System for Agricultural Lending; de-risking lending to the agricultural sector; private sector driven-marketing organizations. 
Agriculture remains the dominant sector in the rural areas of Nigeria. It provides employment for about $60 \%$ of the work force. The diversity of climatic conditions, the richness of soil types and water sources, and the high population density provide great potentials for crop, animal, fish, and tree production. In the 1960s and up to the early 1970s, Nigeria's agriculture flourished. The country was one of the world's highest producers of palm oil, cocoa, and groundnut. Over time, agriculture has declined in importance.

However, there are many signs that agriculture is regaining its past glorious importance. The country is now the largest producer of cassava roots and yam tubers; livestock and soybean production is among the largest in Africa. The share of agriculture in real GDP has been increasing since 1996 and the annual growth of the sector has surpassed population growth in recent years. More importantly, the agricultural sector is receiving the expected attention from policy makers, which is manifested in several new presidential initiatives, e.g., for cassava and for rice. The International Institute of Tropical Agriculture (IITA) salutes these new developments and is glad to contribute to the evolution in the agricultural sector in Nigeria, and elsewhere in sub-Saharan Africa.

Agriculture in Nigeria is a major branch of the economy in Nigeria, providing employment for $70 \%$ of the population. One of the poorest countries in the world, but provide many imports for countries around the world. The sector is being transformed by commercialization at the small, medium and large-scale enterprise levels. In 1990, 82 million hectares out of Nigeria's total land area of about 91 million hectares were found to be arable. 42 percent of the cultivable area was farmed. Much of this land was farmed under the bush fallow system, whereby land is left idle for a period of time to allow natural regeneration of soil fertility. 18 million hectares were classified as permanent pasture, but had the potential to support crops. Most of the 20 million hectares covered by forests and woodlands are believed to have agricultural potential.

Agricultural holdings are small and scattered, and farming is carried out with simple tools. Large-scale agriculture is not common. Agriculture contributed 32\% to GDP in 2010. Major crops include beans, sesame, cashew nuts, cassava, cocoa beans, groundnuts, gum arabic, kolanut, maize (corn), melon, millet, palm kernels, palm oil, plantains, rice, rubber, sorghum, soybeans and yams. However the potential yield is less than actual yield, the yield gap is very high (Table1). 


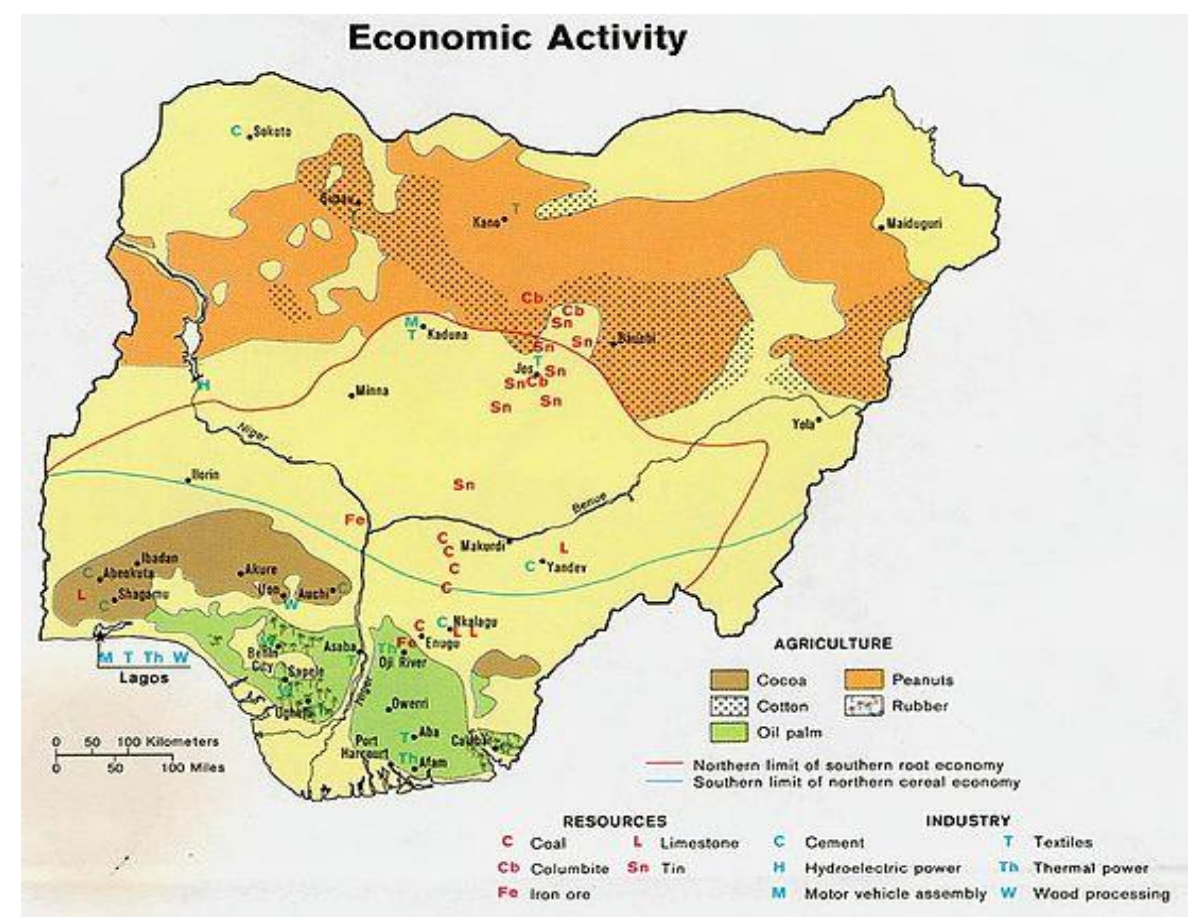

Picture 1. Economic activity in Nigeria

\begin{tabular}{|l|l|l|}
\hline POPULATION OF NIGERIA & 176.6 million & 2013 \\
\hline G.D.P & $\$ 521.8$ Billions & 2013 \\
\hline G.D.P GROWTH & $5.4 \%$ & 2013 \\
\hline INFLACTION & $8.5 \%$ & 2013 \\
\hline
\end{tabular}

Sources: world Bank 2014

Table 1

Yield gaps of selected commodities. (2010/14)

\begin{tabular}{|l|l|l|l|l|}
\hline CROPS & $\begin{array}{l}\text { ACTUAL } \\
\text { YIELD/HA }\end{array}$ & $\begin{array}{l}\text { POTENTIAL } \\
\text { YIELD/HA }\end{array}$ & YIELD GAP\% & $\begin{array}{l}\text { DEVELOPMENT } \\
\text { DOMAIN. }\end{array}$ \\
\hline MILLIET & 1.1 & 5.4 & 391 & NW,NE \\
\hline MAIZE & 2.8 & 7 & 150 & NW \\
\hline SORGHUM & 1.14 & 5 & 339 & NW \\
\hline RICE & 3 & 5 & 67 & NC \\
\hline YAM & 11.36 & 30 & 164 & NC,SE,SS \\
\hline CASSAVA & 12 & 45 & 275 & SW,SS,SE,NC \\
\hline COWPEA & 1.4 & 4 & 186 & NW,NE \\
\hline GROUNDNUT & 1.15 & 3.5 & 204 & NW,NE \\
\hline SOYABEANS & 1.53 & 4 & 161 & NC,NW \\
\hline VEGETABLES & 4.28 & 6.1 & 43 & SW,SS,SE,NC. \\
\hline MELON & 1.1 & 2.5 & 127 & NC \\
\hline TOMATO & 6.9 & 18 & 161 & NW,NE \\
\hline ONION & 15 & 18.5 & 23 & NW,NE \\
\hline GINGER & 6.55 & 50 & 663 & NC \\
\hline COCOA & 0.3 & 1 & 233 & SW \\
\hline
\end{tabular}

Key: $N C=$ Northcentral $; N E=$ Northeast $; N W=$ Northwest $; S E=$ Southeast $;$ SS $=$ Southsouth; SW = Southwest. (2014). Source: Federal livestock department. (2011).

However farming in Nigeria is highly risky. Droughts and epizooty can cause essential damage to a rural producer. In order to risks of agrobusiness in Nigeria business, the state took measures for adoption of the laws promoting development of low-risk agrarian production. 
The Nigeria Incentive-Based Risk-Sharing System for Agricultural Lending (NIRSAL) is a new innovative mechanism targeted at de-risking lending to the agricultural sector, is designed to provide the singular transformational and one bullet solution to break the seeming jinx in Nigeria's agricultural lending and development. The Central Bank of Nigeria (CBN) in August 2010, engaged the Alliance for Green Revolution in Africa (AGRA) to develop the NIRSAL.

NIRSAL is an approach that tackles both the agricultural value chains and the agricultural financing value chain. The goal of NIRSAL is to trigger an agricultural industrialization process through increased production and processing of the greater part of what is produced to boost economic earnings across the value chain.

Besides the markets for agricultural commodities would be strengthened through the establishment of commodity marketing corporations around each of the commodities under the Agricultural Transformation Agenda.

The Federal Government will support the development of private sector driven-marketing organizations to grow the agricultural sector. The scrapping of marketing boards during the implementation of Structural Adjustment Programme (SAP) without any institutions to replace them or play their roles left millions of farmers in a precarious situation making access to market a very serious challenge. One of the effects of this has been price uncertainties and volatilities which left farmers at the mercy of middle-men.

These marketing institutions would be owned by agricultural value-chains and run as private sector led, but government enabled institutions to empower farmers and the value chain actors to generate value. These new institutions, which would be called, marketing corporations, will coordinate production and export of target commodities. They will also attract investment into the sector from Research and Development to infrastructure and processing. They will stimulate the development of tailored financial services to grow the sector.

Growth Enhancement Support Scheme (GESS) represents a policy and pragmatic shift within the existing Fertilizer Market Stabilization Programme and it puts the resource constrained farmer at its center through the provision of series of incentives to encourage the critical actors in the fertilizer value chain to work together to improve productivity, household food security and income of the farmer.

Goals of GESS are:

- $\quad$ Target 5 million farmers in each year for 4 years that will receive GESS in their mobile phone directly totaling 20 million at the end of 4 years.

- $\quad$ To provide support directly to farmers to enable them procure agricultural inputs at affordable prices, at the right time and place.

- $\quad$ To increase productivity of farmers across the length and breadth of the country through increased use of fertilizer i.e. $50 \mathrm{~kg} / \mathrm{ha}$ from $13 \mathrm{~kg} / \mathrm{ha}$.

- $\quad$ Change the role of Government from direct procurement and distribution of fertilizer to a facilitator of procurement, regulator of fertilizer quality and catalyst of active private sector participation in the fertilizer value chain

Thus today the programs directed on infrastructure improvement, creation of jobs and shared wealth in rural areas develop in agrarian and industrial complex of Nigeria. There's an Agricultural Transformation Agenda Support Program Phase 1 (ATASP-1) among them.

The expected impact of this program is to contribute to the private sector-led agricultural growth for food security. Its specific objective is to increase, on a sustainable basis, the income of smallholder farmers and rural entrepreneurs that are engaged in the production, processing, storage and marketing of the priority commodity value chains. ATASP-1 aims to improve agricultural production and productivity. To achieve this, the Program will comprise the following components in Table 2: 
Table 2

The Components of ATASP-1

\begin{tabular}{|c|c|c|}
\hline Component & $\begin{array}{l}\text { Total } \operatorname{cost}(\mathrm{UA} \\
\text { Millions) }\end{array}$ & Component Description \\
\hline $\begin{array}{l}\text { Infrastructure } \\
\text { Development }\end{array}$ & $71.56(55.0 \%)$ & $\begin{array}{l}\text { Rehabilitation of agricultural and ancillary social } \\
\text { infrastructure including } 1,300 \mathrm{~km} \text { of irrigation wa- } \\
\text { ter conveyance canals (Kebbi, 280km; Sokoto, } \\
175 \mathrm{~km} \text {; Niger, 220km; Kano, 230km; Enugu, } \\
125 \mathrm{~km} \text {; Anambra, 75km; and Jigawa } 195 \mathrm{~km}) \text {; } \\
1,007 \text { units of various hydraulic structures (Kebbi, } \\
167 \text {; Sokoto, 120; Niger, 229; Kano, 104; Enugu, } \\
182 \text {; Anambra, 100; and Jigawa 105); } 1,330 \mathrm{~km} \text { of } \\
\text { feeder roads (Kebbi, 265km; Sokoto, 55km; Ni- } \\
\text { ger, 235km; Kano, 330km; Enugu, } 115 \mathrm{~km} \text {; } \\
\text { Anambra, } 80 \mathrm{~km} \text {; and Jigawa } 250 \mathrm{~km}) \text {; rehabilita- } \\
\text { tion of } 35 \text { primary schools ( } 5 \text { per state), } 14 \text { health } \\
\text { centers ( } 2 \text { per state), } 70 \text { potable water supply and } \\
\text { sanitation schemes (10 boreholes and accessories } \\
\text { per state); } 21 \text { demonstration and technology cen- } \\
\text { ters ( } 3 \text { per state), } 21 \text { community markets and stor- } \\
\text { age facilities ( } 3 \text { per state). }\end{array}$ \\
\hline $\begin{array}{l}\text { Commodity value } \\
\text { chain development. }\end{array}$ & $\begin{array}{l}38.10 \\
(29.3 \%)\end{array}$ & $\begin{array}{l}\text { Capacity development for public (agricultural re- } \\
\text { search, extension, relevant Ministries' department } \\
\text { such as Rural Development and of FMARD, } \\
\text { Monitoring and Evaluation for efficient external } \\
\text { supervision), private (MFIs, agro-dealers, etc.) } \\
\text { and community-based (producers' organizations, } \\
\text { cooperatives, inter-professional bodies, etc.) insti- } \\
\text { tutions; training value chain actors in technical } \\
\text { and managerial skills; promoting use of science \& } \\
\text { technology; training in post-harvest reduction } \\
\text { methods including food processing; business and } \\
\text { entrepreneurship training; training of communities } \\
\text { and health workers on prevention and manage- } \\
\text { ment of common diseases as well as good nutri- } \\
\text { tion, sanitation \& hygiene practices; development } \\
\text { of market information system (MIS); management } \\
\text { of environmental and social impacts; implementa- } \\
\text { tion of policies to promote private investment in } \\
\text { agriculture. }\end{array}$ \\
\hline $\begin{array}{l}\text { Program } \\
\text { management }\end{array}$ & $\begin{array}{l}20.43 \\
(15.7 \%)\end{array}$ & $\begin{array}{l}\text { Coordination and supervision of program activi- } \\
\text { ties; and program day to day management based } \\
\text { on adequate results measurement framework; } \\
\text { ESMP implementation and supervision; program } \\
\text { procurement, disbursement, financial manage- } \\
\text { ment, audit and reporting. }\end{array}$ \\
\hline Total & 130.09 & \\
\hline
\end{tabular}


ATASP-1 will be implemented in four Staple Crops Processing Zones (SCPZs) of AdaniOmor, Bida-Badeggi, Kano-Jigawa, Kebbi-Sokoto and cover 21 LGAs in seven States: Anambra (Ogbaru and Orumba North LGAs), Enugu (Uzo Uwani LGA); Jigawa (Hadejia LGA); Kano (Bunkure, Kura and Rano LGAs); Kebbi (Argungu, Bagudo, Birnin Kebbi, Dandi, Ngaski, Shanga and Suru LGAs); Niger (Agaie, Gbako, Lapai, Lavun, Katcha and Mokwa LGAs); and Sokoto (Kware LGA). The Processing Zones are specially delimited contiguous expanses of land in areas of high agricultural production and potential where the localized provision of a well-developed physical infrastructure such as access roads and energy, as well as water, are necessities to support production, processing and marketing activities for selected commodities.

\section{There are factors constraining agricultural performance}

Resource constraints: A major problem of agricultural labor supply arises from the increasing migration of able-bodied youths from rural to urban areas. The consequence of the massive migration of youths is seasonal labor shortage, especially at the peak periods of labor demand (during land preparation, planting, weeding, and harvesting). There is also the problem of low agricultural labor productivity. There is an increasing population pressure on land as well as a declining quality of land. Rate of land improvement is low because of the low rate of capital investment by the predominantly traditional farmers.

Socioeconomic constraints: The socioeconomic problems that constrain Nigeria's agriculture include scarcity and high cost of improved farm inputs, inefficient marketing arrangements characterized by high marketing margins, lack of grades and standards, and lack of legally enforceable ownership and control rights over land which serves as a disincentive to investing in agriculture and which arises from the lack of an appropriate land tenure system. Other socioeconomic factors are inadequate extension services and credit facilities; low rate of growth in international demand for primary export commodities arising largely from competition with synthetic products; low income elasticity of demand; and increasing food deficit and high.

The dependence on food import arising from the disequilibria in national agricultural resource base, a largely traditional agricultural production system, and some domestic population dynamics.

Organizational constraints: Agricultural production is predominantly in the hands of a multitude of small-scale, unorganized farmers scattered across the country. Lack of organization, coupled with the dispersed nature of farm settlements, hinders the participation of farmers in agricultural and rural development. It particularly hinders the supply of extension services, farm credit, and other vital inputs to farmers.

Thus the proposed project has potential to significantly improve the local production of rice, sorghum and cassava in the target Staple Crop Processing Zones (SCPZ). An improvement in the productivity of the Smallholder farmers will translate to improved food security as the country will import less rice. Besides, project development and operation will provide considerable economic opportunity within the local areas like income for material/equipment suppliers, construction contractors and agriculture professionals.

It is therefore recommended that:

- All agricultural and value addition infrastructure must include the requisite waste disposal or handling systems.

- The choice and type of construction materials and finish should maximize the blending concept. 
- It is important that stakeholder organizations such as Local Government Councils (LGCs), EIA Department, NGOs and other interested parties are consulted and kept informed of the implementation progress so that they can play their part.

- Reduction and control of noise levels to minimize any disruption to the living conditions of wildlife be strictly adhered to.

- The land around any sub-project works should be left intact and pollution be minimized.

- $\quad$ Bush clearance should be confined to the absolutely necessary part, buffer strips be maintained and huge indigenous trees in the area should be preserved as much as possible.

- Labor intensive methods should be encouraged as they benefit the local community in terms of job creation. For this the project should employ locals as much as possible to ensure that benefits remain in the area where development is taking place.

- $\quad$ The use of destructive machinery should be avoided as much as possible. Machinery will adversely affect soils and undergrowth.

- The recommended mitigation measures should be implemented to reduce significant environmental impacts.

\section{REFERENCES}

1. Ajakaiye, O. The structural adjustment program and changes in the structure of production in Nigeria 1986-1994. NCEMA Monograph Series No. 9. Ibadan, Nigeria. 1997.

2. Alston, J.M., P.G. Pardey, S. Wood, and L. You. Strategic technology investments for LAC agriculture: a framework for evaluating the local and spillover effects of R\&D. International Food Policy Research Institute, Washington DC, USA. 2000.

3. Balogun, E.D. and M.F. Otu. Credit policies and agricultural development in Nigeria. CBN Economic and Financial Review vol. 29 no.2, June. 1991.

4. CBN. Issues in agricultural input policy: an empirical evaluation of fertilizer production, distribution and price subsidy in Nigeria. 1998.

5. FMARD (Federal Ministry of Agriculture and Rural Development). New Agricultural Policy, Abuja, Nigeria. 2001.

6. Idachaba, F.S. Instability of national agricultural research systems in sub-Saharan African: lessons from Nigeria. ISNAR Research Report No. 13, The Hague, The Netherlands. 1998.

7. Ikpi, A.E. Nigeria's agricultural sector assessment: issues of technology development and transfer. Prepared for USAID/AFR/SD, Washington, DC, USA. 2000.

8. CBN. Statistical Bulletin, Vol. 11 No. 2. 2013.

9. Nigeria ATASP-1 - SESA Summary 2013.

10. World Bank 2014. http://www.worldbank.org/ng 


\title{
УДК 338.43
}

\author{
Нтукидием Инимфон Иманюэин ${ }^{2}$ \\ ФГБОУ Российский университет дружбы народов г. Москва \\ Россия, Москва ${ }^{3}$ \\ Аспирант кафедры «Финансы и кредит» экономического факультета \\ E-mail: inimfonimaenyin@yahoo.com
}

\section{Сельское хозяйство Нигерии: поиск возможностей для роста коммерциализации и инвестиций}

Аннотация. Статья посвящена изучению путей развития сельского хозяйства в республике Нигерия. В настоящее время страна является крупнейшим производителем маниоки и ямса. Сельское хозяйство в Нигерии важнейшая отрасль экономики в стране, обеспечивающая занятость $70 \%$ населения. Однако сельское хозяйство в Нигерии очень рискованно. Засухи и эпизоотии могут причинить существенный ущерб сельской производителя. В целях снижения рисков ведения агробизнеса в Нигерии, государство принимает меры и принимает законы, способствующие снижению уровня риска аграрного производства Нигерии на основе стимулирования разделение риска системы сельскохозяйственного кредитования (NIRSAL). Это новый инновационный механизм, направленный на снижение рисков кредитования аграрного сектора. Федеральное правительство также поддерживает развитие частных производственно-сбытовых организаций в сельскохозяйственном секторе. Рост уровня государственной поддержки на основе Схемы поддержки (GESS) представляет собой политику формирования и совершенствования инфраструктуры села, интенсификации аграрного производства на основе применения удобрений. Таким образом, сегодня программы, направленные на улучшение инфраструктуры, создание рабочих мест и повышение общего благосостояния в сельских районах успешно развиваются в АПК Нигерии. Однако до сих пор существуют факторы, сдерживающие сельскохозяйственное производство (ограниченность ресурсов; социальноэкономические ограничения, организационные ограничения). Автор статьи предлагает пути преодоления этих ограничений и решения проблем.

Ключевые слова: нигерийское сельское хозяйство; аграрное производство в Нигерии; сельский товаропроизводитель; программа снижения рисков в сельском хозяйстве Нигерии; разделение риска в аграрном секторе; развитие инфраструктуры сельскохозяйственного производства Нигерии; кредитование аграрного сектора Нигерии.

Ссылка для цитирования этой статьи:

Нтукидием Инимфон Иманюэин Сельское хозяйство Нигерии: поиск возможностей для роста коммерциализации и инвестиций // Интернет-журнал «НАУКОВЕДЕНИЕ» Том 7, №1 (2015) http://naukovedenie.ru/PDF/66EangVN115.pdf (доступ свободный). Загл. с экрана. Яз. рус., англ. DOI: $10.15862 / 66$ EangVN115

\footnotetext{
2 респ. Нигерия

3 117198, ул. Миклухо-Маклая, д.6
} 


\section{ЛИТЕРАТУРА}

1. Ajakaiye, O. The structural adjustment program and changes in the structure of production in Nigeria 1986-1994. NCEMA Monograph Series No. 9. Ibadan, Nigeria. 1997.

2. Alston, J.M., P.G. Pardey, S. Wood, and L. You. Strategic technology investments for LAC agriculture: a framework for evaluating the local and spillover effects of R\&D. International Food Policy Research Institute, Washington DC, USA. 2000.

3. Balogun, E.D. and M.F. Otu. Credit policies and agricultural development in Nigeria. CBN Economic and Financial Review vol. 29 no.2, June. 1991.

4. CBN. Issues in agricultural input policy: an empirical evaluation of fertilizer production, distribution and price subsidy in Nigeria. 1998.

5. FMARD (Federal Ministry of Agriculture and Rural Development). New Agricultural Policy, Abuja, Nigeria. 2001.

6. Idachaba, F.S. Instability of national agricultural research systems in sub-Saharan African: lessons from Nigeria. ISNAR Research Report No. 13, The Hague, The Netherlands. 1998.

7. Ikpi, A.E. Nigeria's agricultural sector assessment: issues of technology development and transfer. Prepared for USAID/AFR/SD, Washington, DC, USA. 2000.

8. CBN. Statistical Bulletin, Vol. 11 No. 2. 2013.

9. Nigeria ATASP-1 - SESA Summary 2013.

10. World Bank 2014. http://www.worldbank.org/ng

Рецензент: Рыбакова Ольга Викторовна, доктор экономических наук, профессор кафедры экономики и финансов общественного сектора Российской академии народного хозяйства и государственной службы при Президенте РФ. 